Research Article

\title{
HIV-1 Transactivator Protein Induces ZO-1 and Neprilysin Dysfunction in Brain Endothelial Cells via the Ras Signaling Pathway
}

\author{
Wenlin Jiang, ${ }^{1}$ Wen Huang, ${ }^{1}$ Yanlan Chen, ${ }^{2}$ Min Zou, ${ }^{1}$ Dingyue Peng, ${ }^{1}$ and Debing Chen ${ }^{1}$ \\ ${ }^{1}$ Department of Neurology, First Affiliated Hospital, Guangxi Medical University, Nanning 530021, China \\ ${ }^{2}$ Nanxishan Hospital of Guangxi Zhuang Autonomous Region, Guilin 541000, China \\ Correspondence should be addressed to Wen Huang; hwen1229@163.com
}

Received 29 November 2016; Revised 9 February 2017; Accepted 1 March 2017; Published 2 May 2017

Academic Editor: Anna M. Giudetti

Copyright (C) 2017 Wenlin Jiang et al. This is an open access article distributed under the Creative Commons Attribution License, which permits unrestricted use, distribution, and reproduction in any medium, provided the original work is properly cited.

\begin{abstract}
Amyloid beta $(\mathrm{A} \beta)$ deposition is increased in human immunodeficiency virus-1- (HIV-1-) infected brain, but the mechanisms are not fully understood. The aim of the present study was to evaluate the role of Ras signaling in HIV-1 transactivator protein- (Tat-) induced $\mathrm{A} \beta$ accumulation in human cerebral microvascular endothelial cells (HBEC-5i). Cell viability assay showed that $1 \mu \mathrm{g} / \mathrm{mL}$ Tat and $20 \mu \mathrm{mol} / \mathrm{L}$ of the Ras inhibitor farnesylthiosalicylic acid (FTS) had no significant effect on HBEC-5i cell viability after $24 \mathrm{~h}$ exposure. Exposure to Tat decreased protein and mRNA levels of zonula occludens- (ZO-) 1 and A $\beta$-degrading enzyme neprilysin (NEP) in HBEC-5i cells as determined by western blotting and quantitative real-time polymerase chain reaction. Exposure to Tat also increased transendothelial transfer of $\mathrm{A} \beta$ and intracellular reactive oxygen species (ROS) levels; however, these effects were attenuated by FTS. Collectively, these results suggest that the Ras signaling pathway is involved in HIV-1 Tat-induced changes in ZO- 1 and NEP, as well as A $\beta$ deposition in HBEC-5i cells. FTS partially protects blood-brain barrier (BBB) integrity and inhibits $\mathrm{A} \beta$ accumulation.
\end{abstract}

\section{Introduction}

Human immunodeficiency virus-1- (HIV-1-) related cognitive impairment and dementia are more prevalent in older HIV-1-infected individuals $[1,2]$. Amyloid beta $(\mathrm{A} \beta)$ deposition is a characteristic in the HIV-1-infected brains $[1,3,4]$. Reportedly, exposure to HIV-1 increases brain $\mathrm{A} \beta$ levels by stimulating $\mathrm{A} \beta$ formation [5], upregulating amyloid precursor protein expression [6], inhibiting $A \beta$ degradation [7], or altering $A \beta$ transport across the blood-brain barrier (BBB) [8]. The BBB plays a critical role both in HIV-1 trafficking into the brain [9] and in $A \beta$ pathology [1]. The major components of the BBB are brain microvascular endothelial cells [10] joined by tight junctions (TJs) [11]. TJ proteins such as occludin, claudin, and zonula occludens $(\mathrm{ZO})$ play a critical role in maintaining BBB integrity and low permeability [12]. ZO-1 linking the transmembrane TJs (occludin) to actin cytoskeleton plays an important role in barrier resistance and permeability $[13,14]$.
HIV-1 transactivator of transcription (Tat) protein is essential for HIV infection and virus replication [15]. HIV1 Tat is involved in several cellular processes including inducing angiogenesis, modulating cytokine expression, and activating cellular signaling pathways [16]. Tat protein is actively secreted by HIV-1-infected cells $[10,15]$ and may cross the BBB [10] and be taken up by astrocytes and neurons, resulting in neuronal apoptosis and BBB disruption by increasing intracellular calcium and reactive oxygen species (ROS) levels and stimulating inflammation [16]. HIV-1 Tat also inhibits the $A \beta$-degrading enzyme neprilysin and restricts its ability to degrade $\mathrm{A} \beta$, resulting in increased soluble $\mathrm{A} \beta$ levels in cell culture [7]. Cerebral clearance of soluble $\mathrm{A} \beta$ involves both degradation in the brain and transport across the BBB to systemic circulation. Neprilysin-degraded $\mathrm{A} \beta$ is partially removed from the brain by efflux transport at the BBB [17]. The Ras family of small GTPases transmits extracellular signals involved in many cellular processes that regulate cell growth, differentiation, motility, and death. Ras 
is a major hub of many signaling pathways [18]. For example, activation of the Ras/mitogen-activated protein kinase pathway is involved in HIV-1 Tat-induced disruption of TJ proteins in brain endothelial cells [19]. Ras signaling induces the generation of ROS via activating the downstream effector mitogen-activated protein kinase (MEK)/extracellular signalregulated kinases (ERK), resulting in the alteration of TJs and BBB permeability [20]. Farnesylthiosalicylic acid (FTS) is a synthetic and functional Ras inhibitor [21] that has been successfully used in phase II clinical trials of patients with pancreatic and non-small-cell lung cancer [22]. Inhibition of Ras by FTS may ameliorate inflammatory conditions [23]. Ras signaling can be a target for HIV-1 Tat-induced changes of TJ proteins [3], and inhibition may be an appropriate therapeutic intervention [21].

Whether the Ras signaling pathway is involved in HIV-1induced $\mathrm{BBB}$ disruption and $\mathrm{A} \beta$ deposition is not fully understood. The aim of the current study was to evaluate the role of Ras signaling in HIV-1-induced ZO-1 and neprilysin disruption and $\mathrm{A} \beta$ accumulation in HBEC-5i cells.

\section{Materials and Methods}

2.1. Cell Cultures and Treatment. Human cerebral microvascular endothelial cells (HBEC-5i) were purchased from American Type Culture Collection (ATCC, Manassas, VA, USA). The cells were cultured on $0.1 \%$ gelatin solution (ATCC)-coated flasks in DMEM:F12 medium (ATCC) supplemented with $10 \%$ foetal bovine serum (Gibco/ Thermo Fisher, Waltham, MA, USA), $40 \mu \mathrm{g} / \mathrm{mL}$ endothelial growth supplement (ECGS, ATCC), and $1 \%$ penicillinstreptomycin (Beyotime, Shanghai) according to the manufacturer's instructions. HBEC-5i cells were incubated at $37^{\circ} \mathrm{C}$ in a humidified atmosphere of $5 \% \mathrm{CO}_{2}$.

Recombinant HIV-1 Tat clade-B protein (amino acids 1 to 86) was purchased from Prospec (Rehovot, Israel). The previous literature indicated that concentrations of Tat in $\mathrm{HIV}$-infected patients could reach the range of $0.5 \mu \mathrm{g} / \mathrm{mL}$ of serum [24], so this concentration was used in subsequent experiments. Controls consisted of cells treated with $0.02 \%$ DMSO or heat-inactivated Tat $(1 \mu \mathrm{g} / \mathrm{mL})$. Before exposure to $1 \mu \mathrm{g} / \mathrm{mL}$ HIV-1 Tat for 12 or $24 \mathrm{~h}$, confluent HBEC-5i cells were pretreated with $5 \mu \mathrm{mol} / \mathrm{L}$ FTS for $3 \mathrm{~h}$ and FTS was retained in the serum-free cell culture medium during Tat treatment as previously described [25].

2.2. Cell Viability Assay. A density of $1 \times 10^{4}$ cells/well of HBEC-5i cells were seeded onto 96-well plates. After $12 \mathrm{~h}, \mathrm{HBEC}-5 \mathrm{i}$ were treated with Tat at $0,0.25,0.5,1$, or $1.25 \mu \mathrm{g} / \mathrm{mL}$ and heat-inactivated Tat for $24 \mathrm{~h}$ or the Ras inhibitor FTS (Sigma-Aldrich, St. Louis, MO, USA) at 0, $5,10,20,30,40$, or $50 \mu \mathrm{mol} / \mathrm{L}$ for 12,24 , and $48 \mathrm{~h}$. The cells were then incubated with $20 \mu \mathrm{L}$ 3-(4,5-dimethylthiazol-2-yl)-2,5-diphenyltetrazolium bromide solution (MTT, $5 \mathrm{mg} / \mathrm{mL}$; Sigma-Aldrich) for another $4 \mathrm{~h}$. Optical density was measured at $570 \mathrm{~nm}$ using a microwell plate reader (Thermo Scientific). Neither Tat at $1 \mu \mathrm{g} / \mathrm{mL}$ nor FTS at $20 \mu \mathrm{mol} / \mathrm{L}$ for $24 \mathrm{~h}$ had a significant effect on HBEC-5i cell viability.
2.3. Western Blot Analysis. Following treatment, cells were washed three times and lysed using radioimmunoprecipitation assay cell lysis buffer (Beyotime) containing protease inhibitor cocktail tablets (Beyotime). The lysates were collected and centrifuged at $12,000 \mathrm{~g}$ for $15 \mathrm{~min}$, and protein levels were quantified using a BCA Protein Assay Kit (Beyotime). Next, $30 \mu \mathrm{g}$ proteins were separated by SDSPAGE and transferred onto polyvinylidene fluoride membranes $(0.45 \mu \mathrm{m}$; Millipore, Billerica, MA, USA). Membranes were blocked for $1 \mathrm{~h}$ with $5 \%$ fat-free milk at room temperature and then incubated with primary antibodies against $\mathrm{ZO}$ 1 ( $1: 400$, rabbit polyclonal; Abcam, Cambridge, UK), NEP (1:400, rabbit polyclonal; Abcam), and GAPDH (1:5000; Proteintech Group, Chicago, IL, USA) at $4^{\circ} \mathrm{C}$ overnight. The next day, the membranes were washed and incubated with IRDye $680 \mathrm{RD}$ goat anti-rabbit immunoglobulin (Ig) G (1:10,000; LI-COR Biosciences, Lincoln, NE, USA) secondary antibody for $1 \mathrm{~h}$ at room temperature. The detected proteins were then visualized using an Odyssey Infrared Imaging System (LI-COR Biosciences). Band density was analysed by ImageJ software (National Institutes of Health, Bethesda, MD, USA), and signal density was calculated as the ratio of signal intensity to that of GAPDH.

\subsection{Real-Time Reverse Transcription Polymerase Chain} Reaction. After treatment, cells were harvested, total RNA was extracted using TRIzol reagent (TakaraBio, Dalian, Japan), and cDNA was generated from $1 \mu \mathrm{g}$ RNA using the Prime-Script RT reagent kit (Takara) according to the manufacturer's instructions. cDNA was used for quantitative RT-PCR using a Taq PCR Master Mix kit (Takara) and conducted on the StepOnePlus Real-Time PCR System (Applied Biosystems, Foster City, CA, USA) using RT Reaction Mix in a total volume of $20 \mu \mathrm{L}$ at $95^{\circ} \mathrm{C}$ for $30 \mathrm{~s}$, followed by $95^{\circ} \mathrm{C}$ for $5 \mathrm{~s}$, and $60^{\circ} \mathrm{C}$ for $30 \mathrm{~s}$ for 40 cycles. The primer sequences were as follows: $\mathrm{ZO}-1$ (Takara): 5'-GACCAATAGCTGATGTTGCCAGAG-3' and 5'-TGCAGGCGAATAATGCCAGA-3'; NEP (Takara): $5^{\prime}$ TAAGCAGCCTCAGCCGAACC- $3^{\prime}$ and $5^{\prime}$-TTGACATAG TTTGCACAACGTCTCC-3'; and GAPDH (Takara): $5^{\prime}-$ GCACCGTCAAGGCTGAGAAC- $3^{\prime}$ and $5^{\prime}$-TGGTGAAG ACGCCAGTGGA-3'. GAPDH was used to normalize target gene mRNA levels, which were analysed using the $2^{-\Delta \Delta \mathrm{Ct}}$ method.

2.5. Immunofluorescence Microscopy. HBEC-5i cells were seeded onto gelatin-coated circular glass slips in 24-well plates and incubated for $24 \mathrm{~h}$. After treatment, the cells were fixed with $4 \%$ paraformaldehyde (Solarbio, Beijing, China) on ice for $30 \mathrm{~min}$ and permeabilised with $0.1 \%$ TritonX-100 (Beyotime) for $10 \mathrm{~min}$. They were then blocked with $3 \%$ bovine serum albumin (Sigma, St. Louis, MO, USA) for $1 \mathrm{~h}$ at room temperature before overnight incubation with a primary antibody against NEP (1:100, rabbit polyclonal; Abcam) at $4^{\circ} \mathrm{C}$. After washing with phosphate-buffered saline (PBS), the slides were incubated with the Alexa Fluor-488 donkey anti-rabbit (1:500; Invitrogen, Thermo Fisher, Waltham, MA, USA) secondary antibody for $2 \mathrm{~h}$ at room temperature. After washing and staining with 


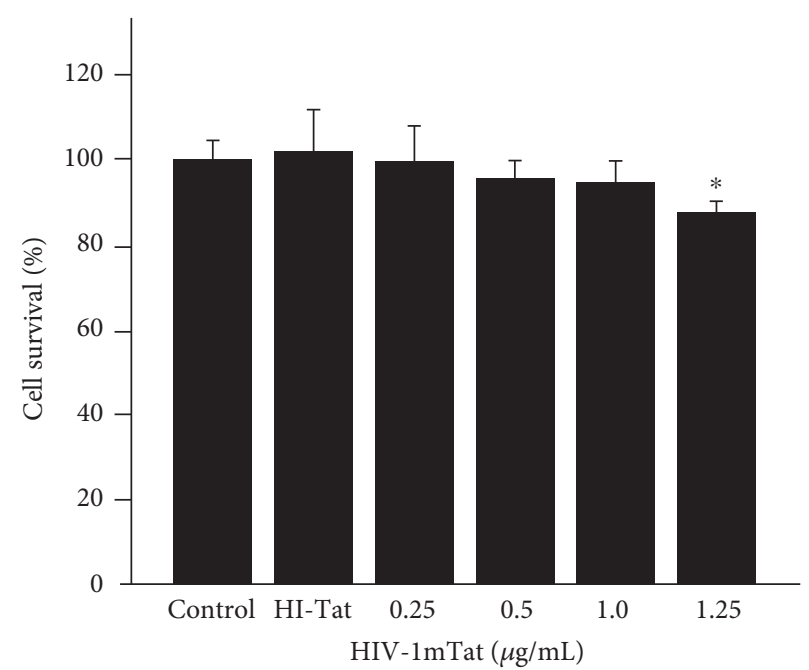

(a)

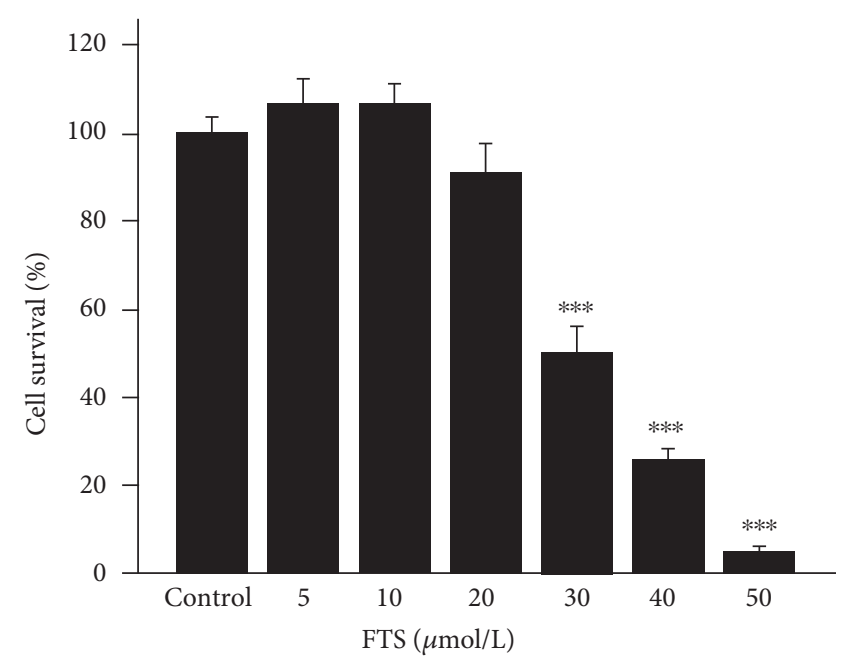

(c)

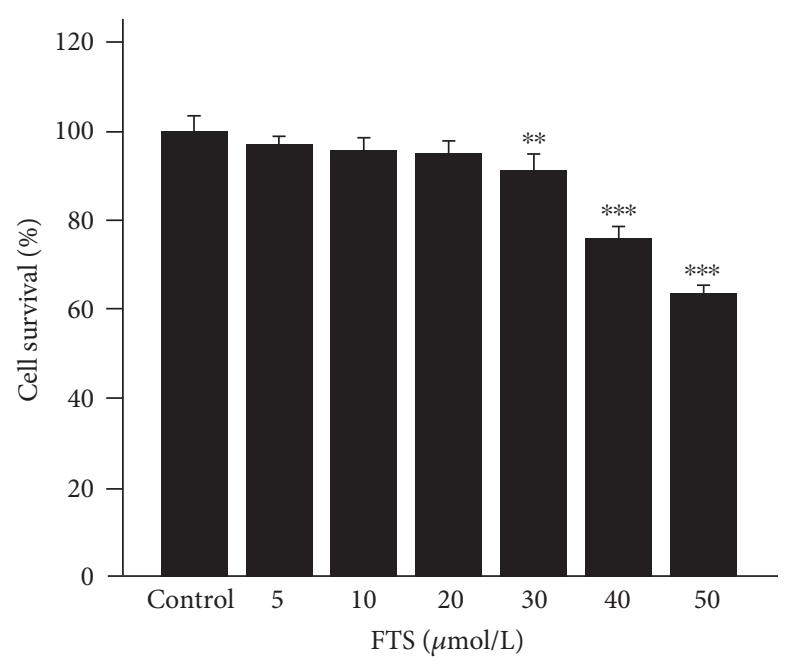

(b)

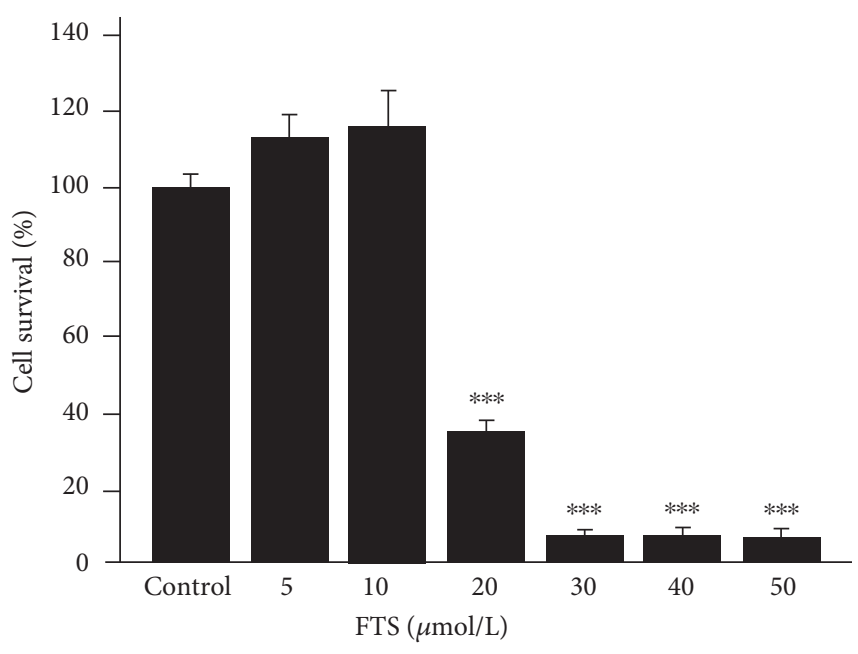

(d)

Figure 1: Cell viability assay. HBEC-5i cells were treated with HIV-1 Tat at $0,0.25,0.5,1$, or $1.25 \mu \mathrm{g} / \mathrm{mL}$ and heat-inactivated Tat for $24 \mathrm{~h}$ (a) or FTS at $0,5,10,20,30,40$, or $50 \mu \mathrm{mol} / \mathrm{L}$ for 12,24 , or $48 \mathrm{~h}$ (b, c, d). Cell viability was not affected by $1 \mu \mathrm{g} / \mathrm{mL}$ HIV-1 Tat or $20 \mu \mathrm{mol} / \mathrm{L}$ FTS for $24 \mathrm{~h}$. Results are expressed as means \pm standard error of the mean $(n=5) .{ }^{*} p<0.05,{ }^{* *} p<0.01$, and ${ }^{* * *} p<0.001$ versus that in the control.

4',6-diamidino-2-phenylindole (Invitrogen), samples were visualized using a fluorescence microscope (OlympusBX53, Tokyo, Japan).

A $\beta$ (1-40) HiLyte (a fluorescently labelled $A \beta$ ) was purchased from AnaSpec (San Jose, CA, USA). A $\beta$ (1-40) HiLyte was first dissolved in PBS and then diluted in cell culture medium as suggested by the manufacturer. Cells were treated with $\mathrm{A} \beta(1-40)$ HiLyte at the concentration of $1 \mu \mathrm{mol} / \mathrm{L}$ for $10 \mathrm{~min}$ in serum-free medium as previously described [1]. The cells were then fixed, washed, and mounted. The fluorescence signal from A $\beta$ (1-40) HiLyte was directly acquired with a fluorescence microscope (OlympusBX53). Both acquisition and quantification were performed using Olympus cellSens Dimension software.

2.6. A $\beta$ (1-40) Transport across HBEC-5i Monolayers. Confluent HBEC-5i cells cultured on Transwell filter inserts (pore size $0.4 \mu \mathrm{m}, 24$-well cell culture plate; Corning, Corning, NY, USA) were pretreated with $5 \mu \mathrm{mol} / \mathrm{L}$ FTS for $3 \mathrm{~h}$ and exposed to $1 \mu \mathrm{g} / \mathrm{mL} \mathrm{HIV-1}$ Tat for $24 \mathrm{~h}$. For the last $20 \mathrm{~min}$ of $\mathrm{HIV}-1$ Tat exposure, $1 \mu \mathrm{mol} / \mathrm{L} \mathrm{A} \beta$ (1-40) HiLyte was added to the upper chamber incubated at $37^{\circ} \mathrm{C}$ in the dark. The fluorescence signal from $\mathrm{A} \beta$ (140) Hilyte as the indicator of transendothelial $A \beta$ transfer was measured using a multidetection microplate reader (Bio-Rad, Hercules, CA, USA) in the lower chamber at $503 \mathrm{~nm}$ (excitation) and $528 \mathrm{~nm}$ (emission).

2.7. Detection of Intracellular ROS. Intracellular ROS levels were quantified using the Reactive Oxygen Species Assay Kit (Beyotime). Cells were washed with PBS, and then, a final concentration of $10 \mathrm{mmol} / \mathrm{L}$ DCFH-DA was added for $30 \mathrm{~min}$ incubation at $37^{\circ} \mathrm{C}$ in the dark. After washing with PBS, the stained cells in the 24 -well plate were visualized by 


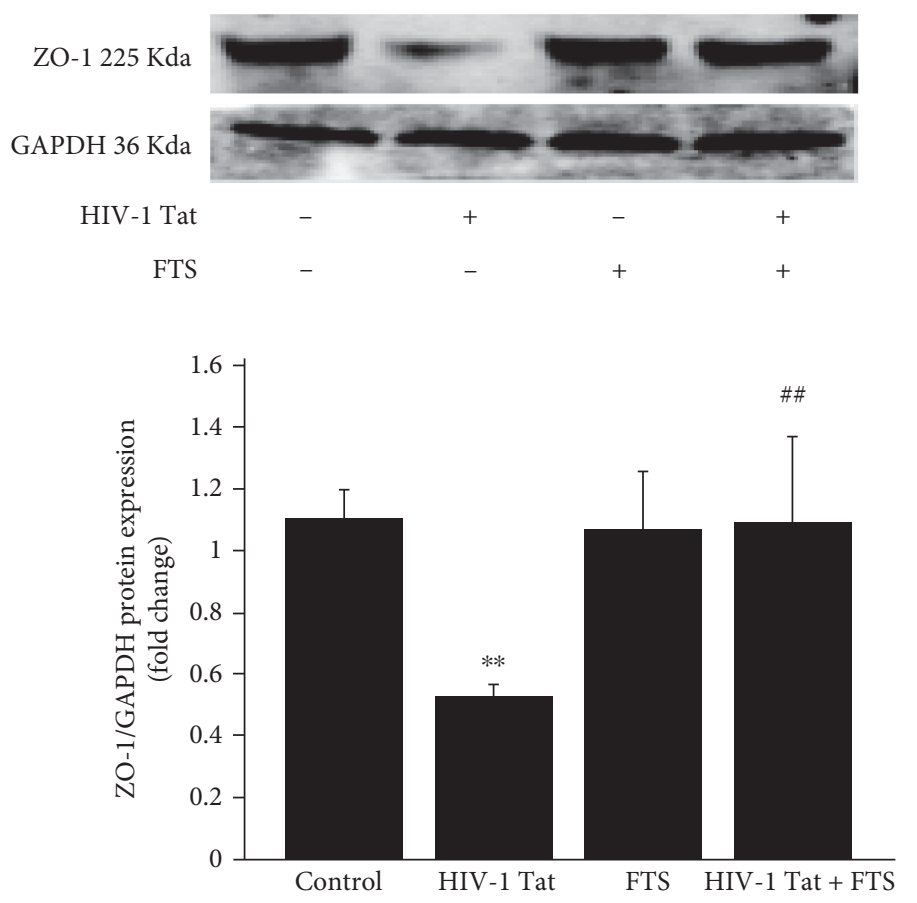

(a)

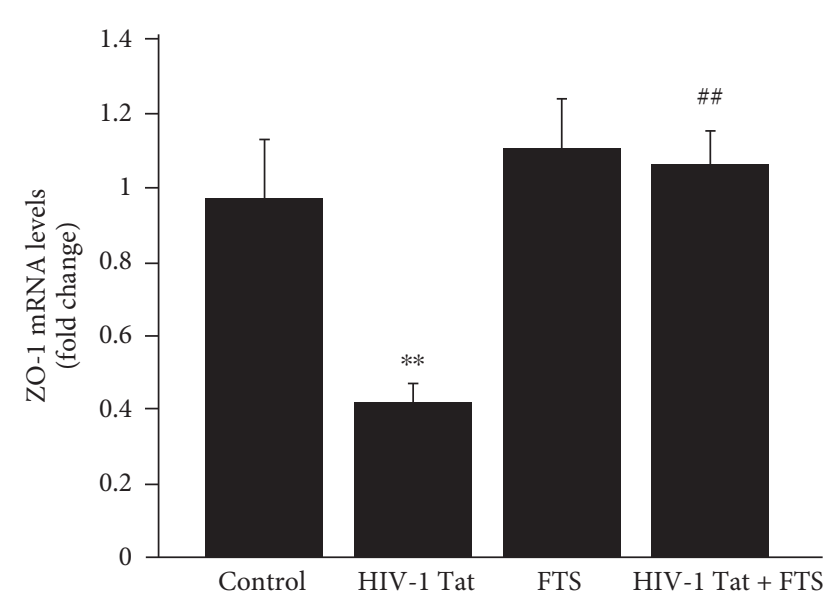

(b)

FIgURE 2: Role of Ras signaling in HIV-1 Tat-induced disruption of ZO-1. Before HIV-1 Tat exposure, HBEC-5i cells were pretreated with $5 \mu \mathrm{mol} / \mathrm{L}$ FTS for $3 \mathrm{~h}$. FTS remained in the culture medium during Tat exposure. The time of Tat exposure was $24 \mathrm{~h}$ for western blotting (a) and $12 \mathrm{~h}$ for RT-PCR (b). HIV-1 Tat exposure induced decreased ZO-1 protein and mRNA levels in HBEC-5i cells. Following cotreatment with FTS and HIV-1 Tat, ZO-1 protein and mRNA levels were significantly increased compared with those in the HIV-1 Tat group. Data are shown as means \pm standard error of the mean $(n=3$ for $(\mathrm{a}), n=5$ for $(\mathrm{b})) .{ }^{* *} p<0.01$ versus control; ${ }^{\# \#} p<0.01$ versus HIV-1 Tat.

inverted fluorescence microscopy (Nikon, Tokyo, Japan). Relative levels of fluorescence in cells were measured with a multidetection microplate reader (Bio-Rad) at $488 \mathrm{~nm}$ (excitation) and $525 \mathrm{~nm}$ (emission). Intracellular ROS level was expressed as the percentage of the control group.

2.8. Statistical Analysis. The data are shown as means \pm standard deviations. Data were analysed using SPSS version 17.0 (SPSS, Chicago, IL, USA). One-way ANOVA was used to compare responses between groups. Differences were considered statistically significant at $p<0.05$.

\section{Results}

3.1. Cell Viability. HBEC-5i viability was tested with MTT assays. Neither HIV-1 Tat at $1 \mu \mathrm{g} / \mathrm{mL}$ nor FTS at $20 \mu \mathrm{mol} / \mathrm{L}$ for $24 \mathrm{~h}$ had a significant effect on HBEC-5i cell viability (Figure 1).

3.2. Ras Signaling Is Involved in HIV-1 Tat-Induced Disruption of ZO-1. To observe the effects of HIV-1 Tat on the TJ protein ZO-1, HBEC-5i cells were exposed to $1 \mu \mathrm{g} /$ $\mathrm{mL} \mathrm{HIV-1} \mathrm{Tat} \mathrm{for} 24 \mathrm{~h}$ (for western blotting) or $12 \mathrm{~h}$ (for real-time RT-PCR). Both protein and mRNA levels of ZO-1 were significantly lower in the HIV-1 Tat group compared to the control group (Figures 2(a) and 2(b)).
To determine if Ras signaling is involved in HIV-1 Tatinduced ZO-1 downregulation, HBEC-5i cells were pretreated for $3 \mathrm{~h}$ with $5 \mu \mathrm{mol} / \mathrm{L}$ FTS, followed by cotreatment with FTS and $1 \mu \mathrm{g} / \mathrm{mL}$ HIV-1 Tat for 24 or $12 \mathrm{~h}$. ZO- 1 protein and mRNA levels were significantly increased following coexposure to FTS and HIV-1 Tat compared with the HIV-1 Tat group (Figures 2(a) and 2(b)).

3.3. Ras Signaling Is Involved in HIV-1 Tat-Induced Regulation of NEP Expression. To investigate whether HIV-1 Tat could affect the expression of NEP in HBEC-5i cells, its expression was detected with western blotting, real-time RTPCR, and immunofluorescence. Treatment with $1 \mu \mathrm{g} / \mathrm{mL}$ HIV-1 Tat for $24 \mathrm{~h}$ (for western blotting and immunofluorescence) or $12 \mathrm{~h}$ (for real-time RT-PCR) significantly downregulated NEP protein and mRNA levels (Figures 3(a) and 3(b)) and resulted in markedly weaker NEP immunoreactivity compared with the control group (Figure 3(c)).

To evaluate whether Ras signaling affects HIV-1 Tatinduced changes in NEP expression, HBEC-5i cells were pretreated with $5 \mu \mathrm{mol} / \mathrm{L}$ FTS for $3 \mathrm{~h}$ and then cotreated with FTS and HIV-1 Tat for 24 or $12 \mathrm{~h}$. FTS increased NEP protein levels (Figure 3(a)). These results were consistent with the NEP mRNA levels in the groups cotreated with FTS and HIV-1 Tat versus the HIV-1 Tat group (Figure 3(b)), and markedly stronger NEP immunoreactivity was noted 


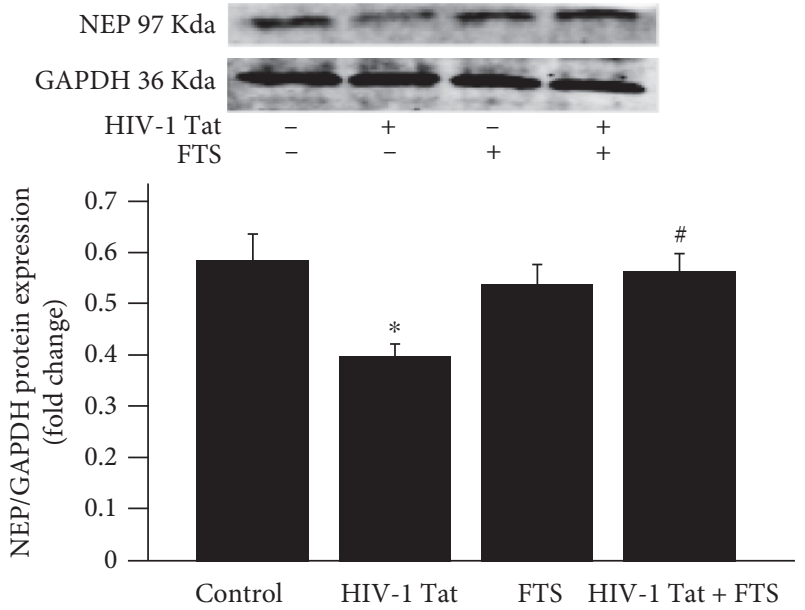

(a)
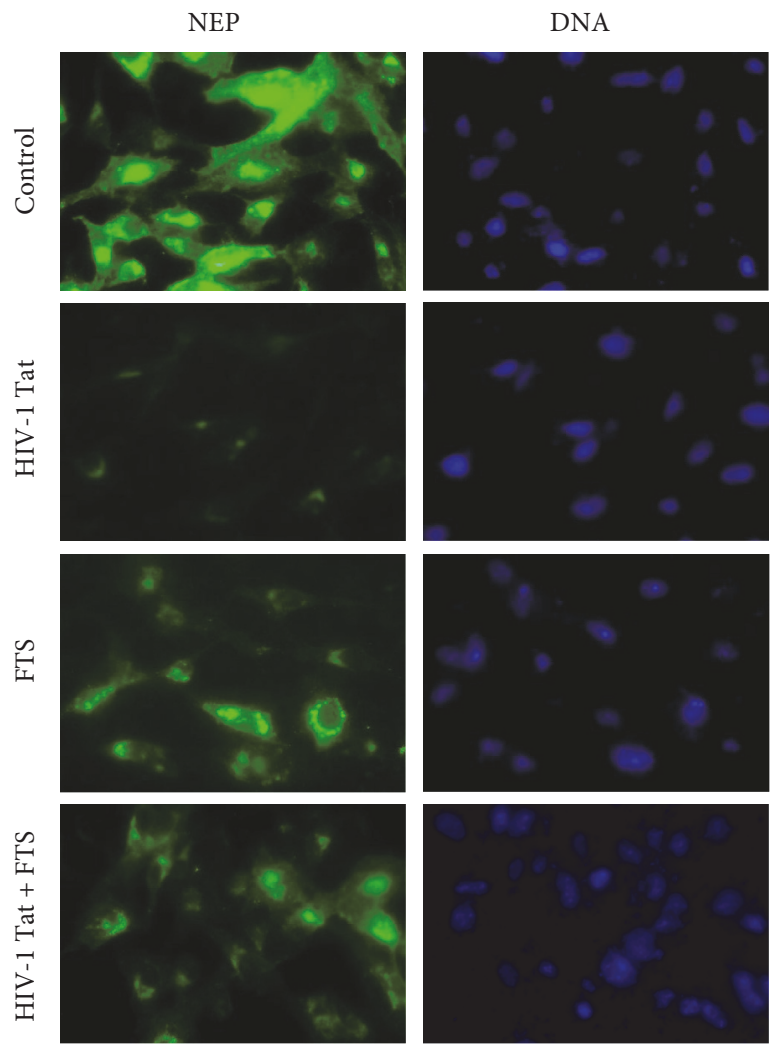

(c)

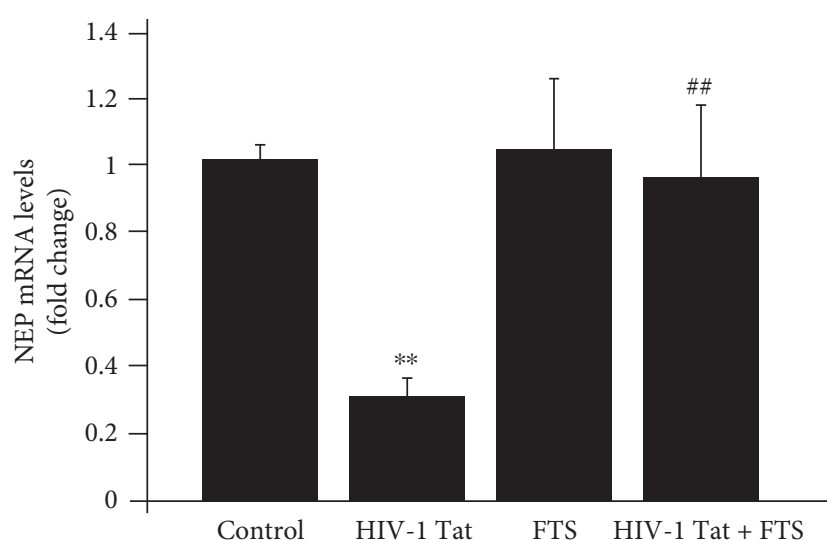

(b)
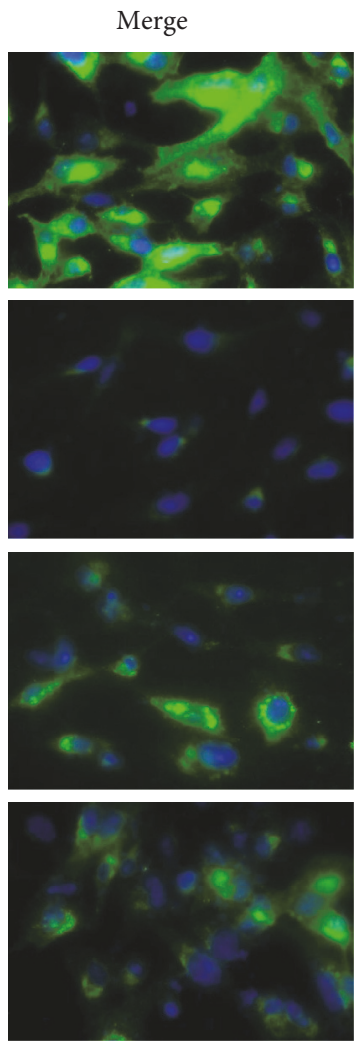

FIgURE 3: Role of Ras signaling in HIV-1 Tat-induced changes in NEP. Exposure to HIV-1 Tat resulted in marked decreases in NEP protein (a) and mRNA (b) and weaker immunoreactivity (c) compared with the control group. Prior to HIV-1 Tat exposure, cells were pretreated with $5 \mu \mathrm{mol} / \mathrm{L}$ FTS for $3 \mathrm{~h}$ with FTS in the culture medium. NEP protein and mRNA levels and immunoreactivity significantly increased with coexposure to FTS and HIV-1 Tat compared with the HIV-1 Tat group. Data are expressed as means \pm standard error of the mean $\left(n=3\right.$ for (a), $n=5$ for (b)). ${ }^{*} p<0.05,{ }^{* *} p<0.01$ versus that in the control; ${ }^{\#} p<0.05,{ }^{\# \#} p<0.01$ versus that in HIV-1 Tat.

in the FTS-treated cells compared with the HIV-1 Tat group (Figure 3(c)).

3.4. Ras Signaling Is Involved in HIV-1 Tat-Induced Accumulation of Exogenous $A \beta$. To observe the combined effects of HIV-1 Tat and exogenous $\mathrm{A} \beta$ on intracellular $\mathrm{A} \beta$ levels, HBEC-5i cells were exposed to $1 \mu \mathrm{g} / \mathrm{mL}$ HIV-1 Tat for $24 \mathrm{~h}$. For the last $10 \mathrm{~min}$ of HIV-1 Tat treatment, A $\beta(1-40)$ HiLyte was added to the culture medium. As shown in Figure 4(a), green fluorescence from A $\beta$ (1-40) HiLyte was significantly increased in the presence of HIV-1 Tat compared with the control group treated with $\mathrm{A} \beta(1-40)$ HiLyte alone. 

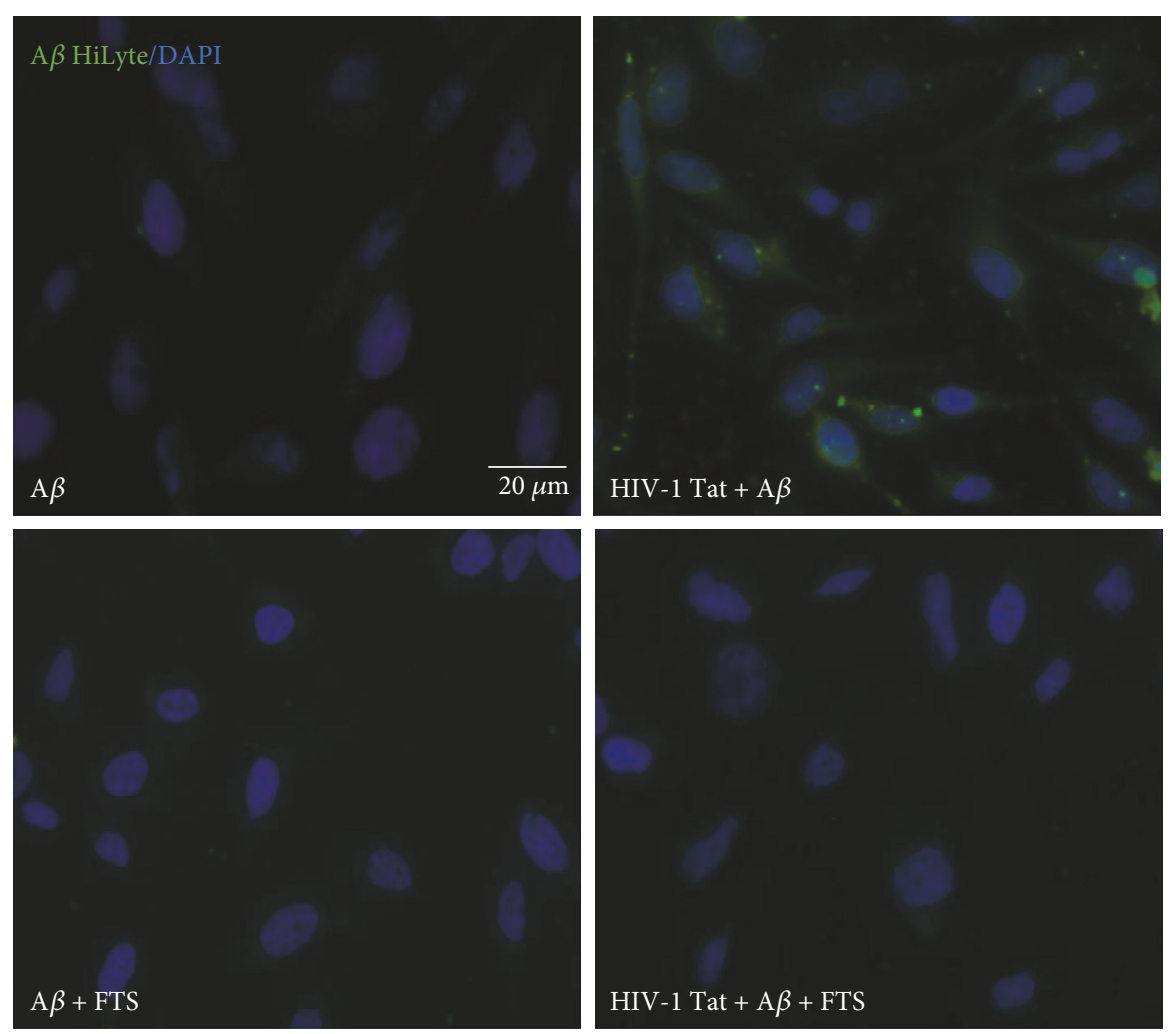

(a)

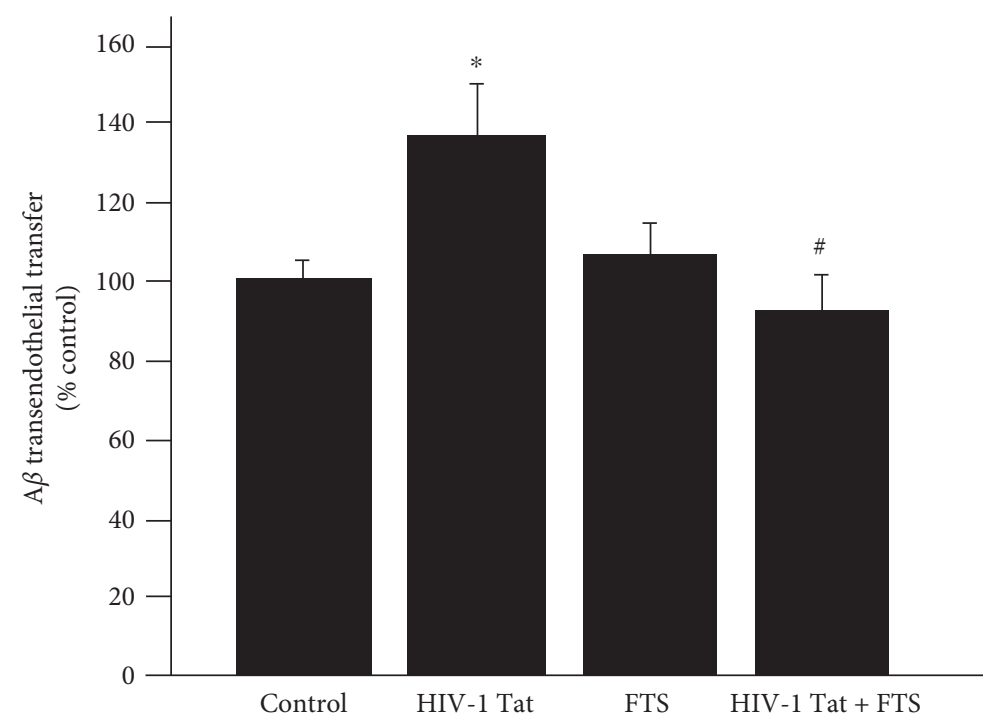

(b)

FIgURE 4: Role of Ras signaling in HIV-1 Tat-induced accumulation of exogenous A $\beta$ in HBEC-5i. HIV-1 Tat exposure markedly increased the accumulation of A $\beta$ (1-40) HiLyte in HBEC-5i. Pretreatment with $5 \mu \mathrm{mol} / \mathrm{L}$ FTS for $3 \mathrm{~h}$ followed by coexposure to HIV-1 Tat and FTS significantly decreased A $\beta$ (1-40) HiLyte accumulation (a). FTS inhibited HIV-1 Tat-induced transendothelial transfer of A $\beta$. Confluent HBEC-5i cells in Transwell filter inserts were exposed to $1 \mu \mathrm{mol} / \mathrm{L} \mathrm{A} \beta$ (1-40) HiLyte for the last 20 min of HIV-1 Tat exposure in the upper chamber, mimicking the blood side of the BBB. The fluorescence signal of A $\beta$ (1-40) HiLyte was measured in the lower chamber, equivalent to the brain side of the BBB (b). Data are expressed as means \pm standard error of the mean $(n=4) .{ }^{*} p<0.05$ versus that in the control; ${ }^{*} p<0.05$ versus that in HIV-1 Tat. 

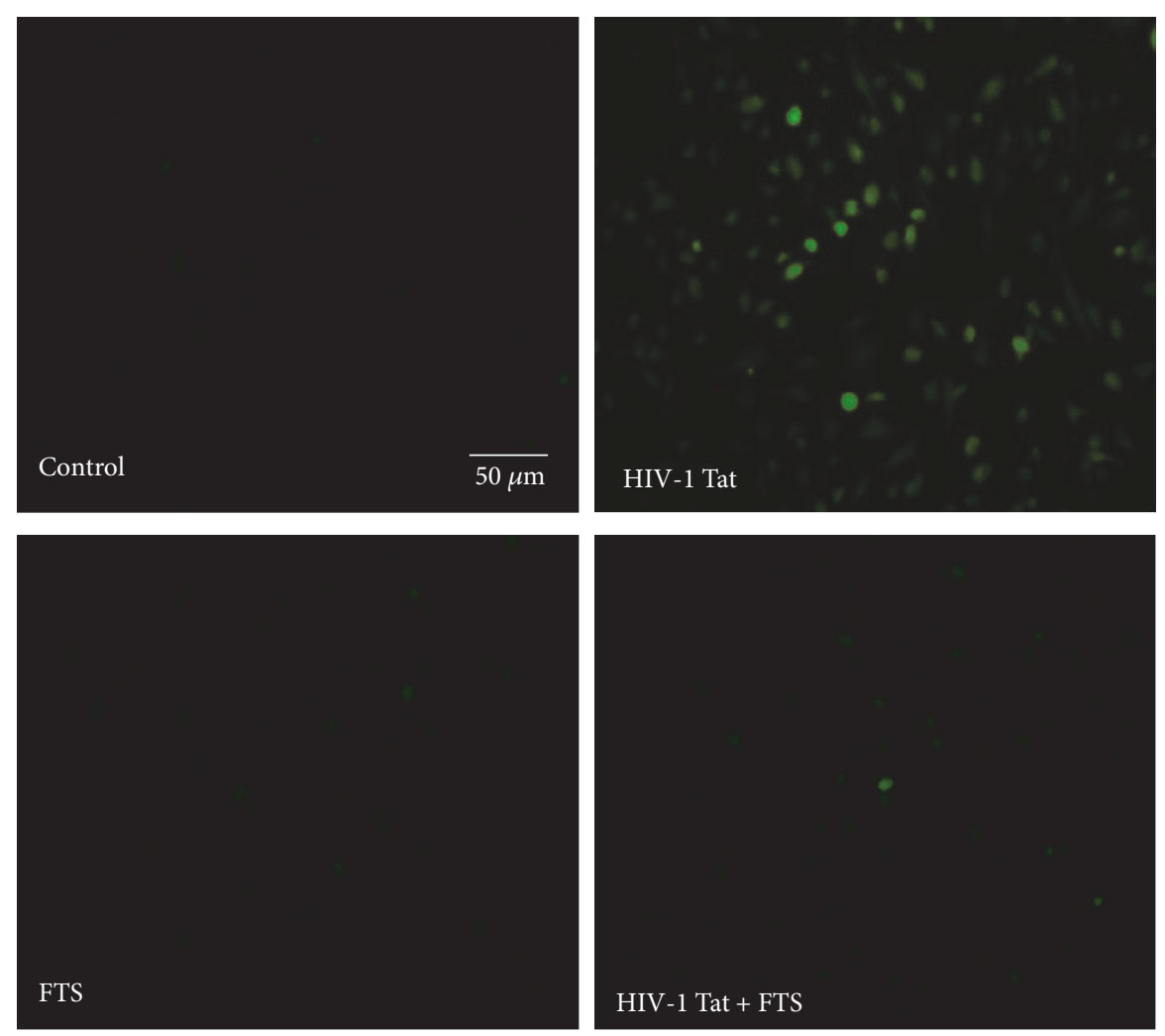

(a)

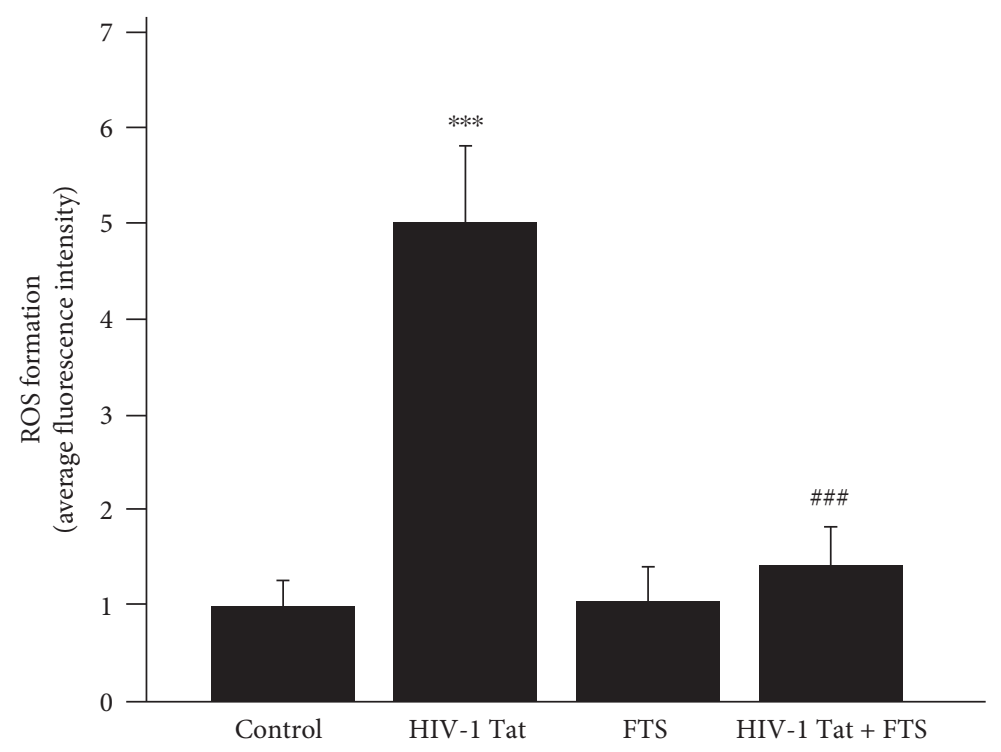

(b)

Figure 5: Role of Ras signaling in HIV-1 Tat-induced changes in intracellular ROS levels. Exposure to HIV-1 Tat for $24 \mathrm{~h}$ significantly increased intracellular ROS levels in HBEC-5i cells. Pretreatment with $5 \mu \mathrm{mol} / \mathrm{L}$ FTS and then coexposure to HIV-1 Tat and FTS markedly attenuated HIV-1 Tat-induced intracellular ROS production. Results are shown as means \pm standard error of the mean $(n=4)$. ${ }^{* * *} p<0.01$ versus that in the control; ${ }^{\# \# \#} p<0.01$ versus that in HIV-1 Tat.

To explore whether Ras signaling is involved in HIV-1 Tat-induced effects of exogenous A $\beta$, HBEC-5i cells were pretreated with $5 \mu \mathrm{mol} / \mathrm{L}$ FTS for $3 \mathrm{~h}$ followed by coexposure to FTS and $1 \mu \mathrm{g} / \mathrm{mL}$ HIV-1 Tat for $24 \mathrm{~h}$. As shown in Figure 4(a), FTS pretreatment prior to coexposure to HIV-1
Tat and FTS markedly decreased HIV-1 Tat-induced accumulation of $\mathrm{A} \beta(1-40)$ HiLyte.

To evaluate the effect of HIV-1 Tat and/or FTS on A $\beta$ transfer across HBEC-5i monolayers, HBEC-5i cells were exposed to $1 \mu \mathrm{mol} / \mathrm{L} \mathrm{A} \beta(1-40)$ HiLyte during HIV-1 Tat 
treatment in a Transwell model system. This led to significant transendothelial $\mathrm{A} \beta$ transfer, which was significantly attenuated by a $3 \mathrm{~h}$ pretreatment with $5 \mu \mathrm{mol} / \mathrm{L}$ FTS before cotreatment with HIV-1 Tat and FTS (Figure 4(b)).

3.5. ROS Production Induced by HIV-1 Tat in HBEC-5i Is Attenuated by Ras Inhibition. To observe the effects of HIV-1 Tat on intracellular ROS levels, overall intracellular ROS production in HBEC-5i cells was assessed with DCFDA staining. Exposure to HIV-1 Tat significantly increased intracellular ROS levels, but this was ameliorated by pretreatment with $5 \mu \mathrm{mol} / \mathrm{L}$ FTS (Figure 5).

\section{Discussion}

HIV-1 Tat protein is regarded a pathogenic factor in HIVassociated neurocognitive disorders (HAND) [26-29]; however, how HIV-1 Tat induces the development of AD-like pathology in HIV-1-infected patients is not fully understood. HAND in older patients seems to be linked to early betaamyloidosis [3, 8]. HIV-1 Tat is reportedly both neuroexcitatory and neurotoxic [30] and can enhance the adhesion of monocytes and $\mathrm{T}$ cells to the endothelium both in vivo and in vitro [31]. A previous study found that two mechanisms underlying HIV-1 Tat-induced BBB destruction were elevated cellular oxidative stress and stimulated inflammatory responses [32]. Our previous study reported that HIV-1 Tat disrupted the TJ protein occludin, downregulated lowdensity lipoprotein receptor-related protein 1 expression, and even upregulated the expression of a receptor for advanced glycation end products, but all of these outcomes were attenuated by inhibiting Rho/ROCK signaling [33]. A functionally impaired $\mathrm{BBB}$ with deficient $\mathrm{A} \beta$ clearance could lead to brain $\mathrm{A} \beta$ accumulation [11]; therefore, the BBB is critical for preventing $\mathrm{A} \beta$ deposition in the HIV-infected brain.

HIV-1 Tat activates Ras and then leads to ERK phosphorylation in endothelial cells [34]. Ras signaling induces ROS generation via the downstream effector MEK/ERK [20], and oxidative stress may be an early step in Tatinduced neurotoxicity [35]. The elements of the Ras signaling cascade are involved in proinflammatory signal transduction [36]. Ras proteins can also activate the immune system [23]. Inhibition of the Ras pathway by FTS was previously found to protect brain endothelial cells from Tat-induced disruption of TJ proteins [25]. ZO-1 acts as a scaffold protein linking occludin to the actin cytoskeleton, and it plays a critical role in maintaining $\mathrm{BBB}$ resistance and permeability [14]. Knocking down ZO-1 with siRNA leads to barrier hyperpermeability [36]. HBEC-5i cells have major characteristics of cerebral endothelial cells, such as high transendothelial electrical resistance (TEER) and low permeability [37]. A previous study demonstrated that exposure to HIV-1 Tat increased permeability and decreased TEER of brain microvascular endothelial cells [38]. In accordance with the earlier study [25], in the present study, HIV-1 Tat-mediated downregulation of ZO-1 protein and mRNA levels was attenuated by inhibiting Ras signaling with FTS. Collectively, these findings indicate that FTS protected against HIV-1 Tat-induced $\mathrm{BBB}$ dysfunction partly by inhibiting Ras signaling.
NEP is considered a critical $A \beta$-degrading enzyme in the brain [39] that can degrade both extracellular and intracellu$\operatorname{lar} \mathrm{A} \beta$ [4]. Levels were increased obviously in the brains of NEP knockout mice [40]. However, the mechanisms of Tatinduced inhibition of NEP are relatively unknown. A previous study reported that the regulation of NEP activity may involve MEK/ERK signaling; specifically, MEK inhibition increases NEP activity [41]. In addition, increasing intracellular ROS production may also downregulate NEP expression in vascular endothelial cells [42]. In the present study, HIV - 1 Tat treatment reduced NEP protein and mRNA levels; however, these effects were diminished by FTS treatment, and the effect of HIV-1 Tat on weaker NEP immunoreactivity was reversed by FTS. Exposure to HIV-1 Tat also significantly elevated intracellular ROS levels, which were decreased by FTS. These results suggest that FTS may partly protect against HIV-1 Tat-induced inhibition of NEP by ameliorating oxidative stress (decreased ROS formation) and inhibiting Ras cascades.

A previous study demonstrated that Tat clade- $B$ may possess a unique ability to directly stimulate both $\mathrm{A} \beta$ formation and cell-bound $\mathrm{A} \beta$ accumulation [5]. Exposure to HIV1 also increases $\mathrm{A} \beta$ transendothelial transfer [1]. $\mathrm{A} \beta$ is a proinflammatory factor that may induce chronic neuroinflammatory responses and damage the endothelium [8]. $\mathrm{A} \beta$ toxicity in the brain vasculature seems to induce ROS production [1]. In accordance with the earlier findings [3], we showed that treatment with exogenous $\mathrm{A} \beta$ (1-40) HiLyte increased intracellular $\mathrm{A} \beta$ levels, and this effect was further enhanced by the presence of HIV-1 Tat. Notably, inhibition of Ras by FTS effectively prevented HIV-1 Tat-mediated $\mathrm{A} \beta$ accumulation. In addition, Tat treatment enhanced transendothelial transfer of $\mathrm{A} \beta$ (1-40) HiLyte; this finding is in conformity with the earlier findings [8]; however, this effect was attenuated by Ras inhibition. These data suggest that inhibiting Ras may attenuate HIV-1 Tat-induced $\mathrm{A} \beta$ accumulation and transendothelial transfer.

In summary, inhibition of Ras signaling in HBEC-5i cells significantly attenuated HIV-1 Tat-induced disruption of ZO-1 and NEP, decreased HIV-1 Tat-induced intracellular ROS formation, and protected against HIV-1 Tat-induced $\mathrm{A} \beta$ accumulation. These findings clarify the possible mechanisms involved in HIV-1-induced $\mathrm{A} \beta$ accumulation in the brain. They also indicate a potential protective effect of FTS on HIV-1 Tat-mediated BBB dysfunction and $\mathrm{A} \beta$ accumulation. Targeting the Ras signaling pathway may be a promising approach for HAND.

\section{Conflicts of Interest}

The authors declare that they have no conflicts of interest.

\section{Acknowledgments}

This work was supported by the National Nature Science Foundation of China (81371333, 81160152, and 2013GXNSFCA019013). 


\section{References}

[1] I. E. Adrás and M. Toborek, "HIV-1 stimulates nuclear entry of amyloid beta via dynamin dependent EEA1 and TGFbeta/Smad signaling," Experimental Cell Research, vol. 323, no. 1, pp. 66-76, 2014.

[2] V. Valcour, C. Shikuma, B. Shiramizu et al., "Higher frequency of dementia in older HIV-1 individuals: the Hawaii Aging with HIV-1 Cohort," Neurology, vol. 63, no. 5, pp. 822-827, 2004.

[3] I. E. András, S. Y. Eum, and M. Toborek, "Lipid rafts and functional caveolae regulate HIV-induced amyloid beta accumulation in brain endothelial cells," Biochemical and Biophysical Research Communications, vol. 421, no. 2, pp. 177-183, 2012.

[4] C. L. Achim, A. Adame, W. Dumaop, I. P. Everall, E. Masliah, and Neurobehavioral Research Center, "Increased accumulation of intraneuronal amyloid beta in HIV-infected patients," Journal of Neuroimmune Pharmacology, vol. 4, no. 2, pp. 190-199, 2009.

[5] M. Y. Aksenov, M. V. Aksenova, C. F. Mactutus, and R. M. Booze, "HIV-1 protein-mediated amyloidogenesis in rat hippocampal cell cultures," Neuroscience Letters, vol. 475, no. 3, pp. 174-178, 2010.

[6] J. Zhang, J. Liu, B. Katafiasz, H. Fox, and H. Xiong, "HIV-1 gp120-induced axonal injury detected by accumulation of beta-amyloid precursor protein in adult rat corpus callosum," Journal of Neuroimmune Pharmacology, vol. 6, no. 4, pp. 650657, 2011.

[7] H. C. Rempel and L. Pulliam, "HIV-1 Tat inhibits neprilysin and elevates amyloid beta," Aids, vol. 19, no. 2, pp. 127-135, 2005.

[8] I. E. András, S. Y. Eum, W. Huang, Y. Zhong, B. Hennig, and M. Toborek, "HIV-1-induced amyloid beta accumulation in brain endothelial cells is attenuated by simvastatin," Molecular and Cellular Neurosciences, vol. 43, no. 2, pp. 232-243, 2010.

[9] W. Huang, S. Y. Eum, I. E. András, B. Hennig, and M. Toborek, "PPARalpha and PPARgamma attenuate HIVinduced dysregulation of tight junction proteins by modulations of matrix metalloproteinase and proteasome activities," The FASEB Journal, vol. 23, no. 5, pp. 1596-1606, 2009.

[10] S. M. Woollard, B. Bhargavan, F. Yu, and G. D. Kanmogne, "Differential effects of Tat proteins derived from HIV-1 subtypes B and recombinant CRF02_AG on human brain microvascular endothelial cells: implications for blood-brain barrier dysfunction," Journal of Cerebral Blood Flow and Metabolism, vol. 34, no. 6, pp. 1047-1059, 2014.

[11] I. E. András and M. Toborek, "Amyloid beta accumulation in HIV-1-infected brain: the role of the blood brain barrier," IUBMB Life, vol. 65, no. 1, pp. 43-49, 2013.

[12] A. Banerjee, X. Zhang, K. R. Manda, W. A. Banks, and N. Ercal, "HIV proteins (gp120 and Tat) and methamphetamine in oxidative stress-induced damage in the brain: potential role of the thiol antioxidant $\mathrm{N}$-acetylcysteine amide," Free Radical Biology \& Medicine, vol. 48, no. 10, pp. 1388-1398, 2010.

[13] P. Dalvi, K. Wang, J. Mermis et al., "HIV-1/cocaine induced oxidative stress disrupts tight junction protein-1 in human pulmonary microvascular endothelial cells: role of Ras/ERK1/2 pathway," PloS One, vol. 9, no. 1, article e85246, 2014.

[14] H. Alluri, R. L. Wilson, C. Anasooya Shaji et al., "Melatonin preserves blood-brain barrier integrity and permeability via matrix metalloproteinase-9 inhibition," PloS One, vol. 11, no. 5, article e0154427, 2016.

[15] I. E. András, G. Rha, W. Huang et al., "Simvastatin protects against amyloid beta and HIV-1 Tat-induced promoter activities of inflammatory genes in brain endothelial cells," Molecular Pharmacology, vol. 73, no. 5, pp. 1424-1433, 2008.

[16] J. Kim, J. H. Yoon, and Y. S. Kim, "HIV-1 Tat interacts with and regulates the localization and processing of amyloid precursor protein," PloS One, vol. 8, no. 11, article e77972, 2013.

[17] S. Ito, K. Matsumiya, S. Ohtsuki, J. Kamiie, and T. Terasaki, "Contributions of degradation and brain-to-blood elimination across the blood-brain barrier to cerebral clearance of human amyloid-beta peptide (1-40) in mouse brain," Journal of Cerebral Blood Flow and Metabolism, vol. 33, no. 11, pp. 1770-1777, 2013.

[18] E. Schmukler, E. Grinboim, S. Schokoroy et al., "Ras inhibition enhances autophagy, which partially protects cells from death," Oncotarget, vol. 4, no. 1, pp. 142-152, 2013.

[19] Y. Zhong, B. Hennig, and M. Toborek, "Intact lipid rafts regulate HIV-1 Tat protein-induced activation of the Rho signaling and upregulation of P-glycoprotein in brain endothelial cells," Journal of Cerebral Blood Flow and Metabolism, vol. 30, no. 3, pp. 522-533, 2010.

[20] D. A. Mayes, T. A. Rizvi, H. Titus-Mitchell et al., "Nf1 loss and Ras hyperactivation in oligodendrocytes induce NOS-driven defects in myelin and vasculature," Cell Reports, vol. 4, no. 6, pp. 1197-1212, 2013.

[21] E. Schmukler, E. Wolfson, R. Haklai, G. Elad-Sfadia, Y. Kloog, and R. Pinkas-Kramarski, "Chloroquine synergizes with FTS to enhance cell growth inhibition and cell death," Oncotarget, vol. 5, no. 1, pp. 173-184, 2014.

[22] E. Bustinza-Linares, R. Kurzrock, and A. M. Tsimberidou, "Salirasib in the treatment of pancreatic cancer," Future Oncology, vol. 6, no. 6, pp. 885-891, 2010.

[23] E. Aizman, E. Blacher, O. Ben-Moshe, T. Kogan, Y. Kloog, and A. Mor, "Therapeutic effect of farnesylthiosalicylic acid on adjuvant-induced arthritis through suppressed release of inflammatory cytokines," Clinical and Experimental Immunology, vol. 175, no. 3, pp. 458-467, 2014.

[24] A. Poggi, R. Carosio, D. Fenoglio et al., "Migration of V delta 1 and $\mathrm{V}$ delta $2 \mathrm{~T}$ cells in response to CXCR3 and CXCR4 ligands in healthy donors and HIV-1-infected patients: competition by HIV-1 Tat," Blood, vol. 103, no. 6, pp. 2205-2213, 2004.

[25] Y. Zhong, E. J. Smart, B. Weksler, P. O. Couraud, B. Hennig, and M. Toborek, "Caveolin-1 regulates human immunodeficiency virus-1 Tat-induced alterations of tight junction protein expression via modulation of the Ras signaling," The Journal of Neuroscience, vol. 28, no. 31, pp. 7788-7796, 2008.

[26] L. Agrawal, J. P. Louboutin, B. A. Reyes, E. J. Van Bockstaele, and D. S. Strayer, "HIV-1 Tat neurotoxicity: a model of acute and chronic exposure, and neuroprotection by gene delivery of antioxidant enzymes," Neurobiology of Disease, vol. 45, no. 2, pp. 657-670, 2012.

[27] L. Buscemi, D. Ramonet, and J. D. Geiger, "Human immunodeficiency virus type- 1 protein Tat induces tumor necrosis factor-alpha-mediated neurotoxicity," Neurobiology of Disease, vol. 26, no. 3, pp. 661-670, 2007. 
[28] J. E. King, E. A. Eugenin, C. M. Buckner, and J. W. Berman, "HIV tat and neurotoxicity," Microbes and Infection / Institut Pasteur, vol. 8, no. 5, pp. 1347-1357, 2006.

[29] X. Chen, L. Hui, N. H. Geiger, N. J. Haughey, and J. D. Geiger, "Endolysosome involvement in HIV-1 transactivator protein-induced neuronal amyloid beta production," Neurobiology of Aging, vol. 34, no. 10, pp. 2370-2378, 2013.

[30] F. Niu, H. Yao, W. Zhang, R. L. Sutliff, and S. Buch, "Tat 101-mediated enhancement of brain pericyte migration involves platelet-derived growth factor subunit B homodimer: implications for human immunodeficiency virus-associated neurocognitive disorders," The Journal of Neuroscience, vol. 34, no. 35, pp. 11812-11825, 2014.

[31] K. Matzen, A. E. Dirkx, M. G. Oude Egbrink et al., "HIV-1 Tat increases the adhesion of monocytes and T-cells to the endothelium in vitro and in vivo: implications for AIDSassociated vasculopathy," Virus Research, vol. 104, no. 2, pp. 145-155, 2004.

[32] M. Toborek, Y. W. Lee, H. Pu et al., "HIV-Tat protein induces oxidative and inflammatory pathways in brain endothelium," Journal of Neurochemistry, vol. 84, no. 1, pp. 169-179, 2003.

[33] Y. Chen, W. Huang, W. Jiang, X. Wu, B. Ye, and X. Zhou, "HIV-1 Tat regulates occludin and Abeta transfer receptor expression in brain endothelial cells via Rho/ROCK signaling pathway," Oxidative Medicine and Cellular Longevity, vol. 2016, Article ID 4196572, p. 9, 2016.

[34] R. F. Wu, Z. Ma, D. P. Myers, and L. S. Terada, "HIV-1 Tat activates dual Nox pathways leading to independent activation of ERK and JNK MAP kinases," The Journal of Biological Chemistry, vol. 282, no. 52, pp. 37412-37419, 2007.

[35] W. Huang, L. Chen, B. Zhang, M. Park, and M. Toborek, "PPAR agonist-mediated protection against HIV Tatinduced cerebrovascular toxicity is enhanced in MMP-9deficient mice," Journal of Cerebral Blood Flow and Metabolism, vol. 34, no. 4, pp. 646-653, 2014.

[36] M. Strazza, V. Pirrone, B. Wigdahl, and M. R. Nonnemacher, "Breaking down the barrier: the effects of HIV-1 on the blood-brain barrier," Brain Research, vol. 1399, pp. 96-115, 2011.

[37] S. C. Wassmer, V. Combes, F. J. Candal, I. Juhan-Vague, and G. E. Grau, "Platelets potentiate brain endothelial alterations induced by plasmodium falciparum," Infection and Immunity, vol. 74, no. 1, pp. 645-653, 2006.

[38] R. Mishra and S. K. Singh, "HIV-1 Tat C phosphorylates VEcadherin complex and increases human brain microvascular endothelial cell permeability," BMC Neuroscience, vol. 15, no. 80, p. 12, 2014.

[39] B. Spencer, R. A. Marr, R. Gindi et al., "Peripheral delivery of a CNS targeted, metalo-protease reduces Ab toxicity in a mouse model of Alzheimer's disease," PloS One, vol. 6, no. 1, article e16575, 2011.

[40] N. Iwata, S. Tsubuki, Y. Takaki et al., "Metabolic regulation of brain Abeta by neprilysin," Science, vol. 292, no. 5521, pp. 1550-1552, 2001.

[41] N. Kakiya, T. Saito, P. Nilsson et al., "Cell surface expression of the major amyloid-beta peptide (Abeta)-degrading enzyme, neprilysin, depends on phosphorylation by mitogen-activated protein kinase/extracellular signal-regulated kinase kinase (MEK) and dephosphorylation by protein phosphatase 1a,"
The Journal of Biological Chemistry, vol. 287, no. 35, pp. 29362-29372, 2012.

[42] P. A. Fitzpatrick, A. F. Guinan, T. G. Walsh et al., "Down-regulation of neprilysin (EC3.4.24.11) expression in vascular endothelial cells by laminar shear stress involves NADPH oxidase-dependent ROS production," The International Journal of Biochemistry \& Cell Biology, vol. 41, no. 11, pp. 22872294, 2009. 


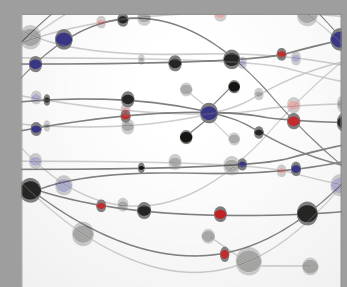

The Scientific World Journal
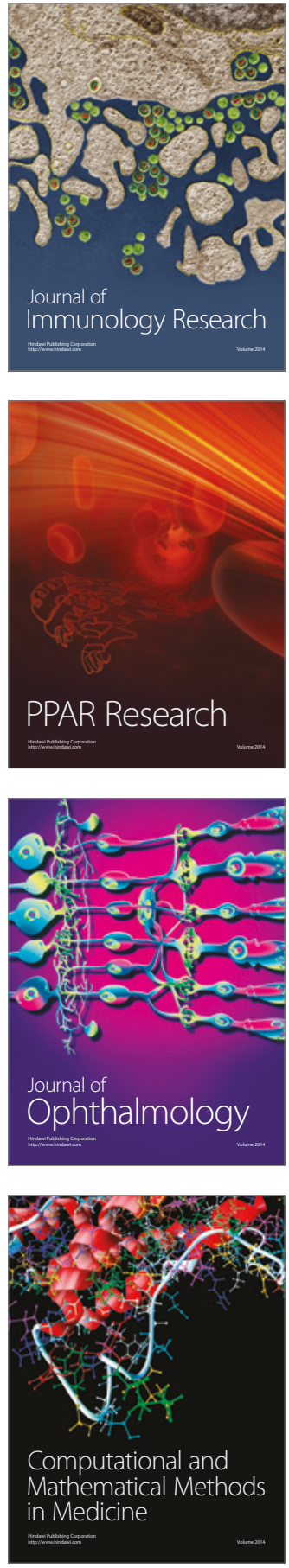

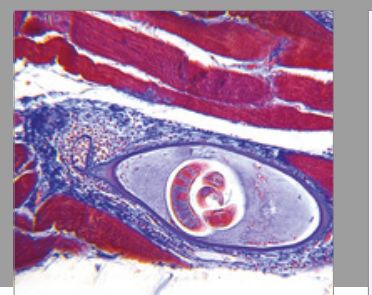

Gastroenterology Research and Practice
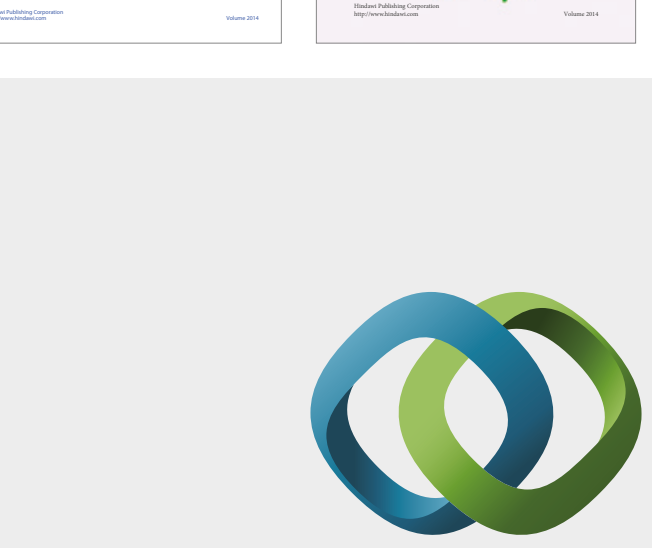

\section{Hindawi}

Submit your manuscripts at

https://www.hindawi.com
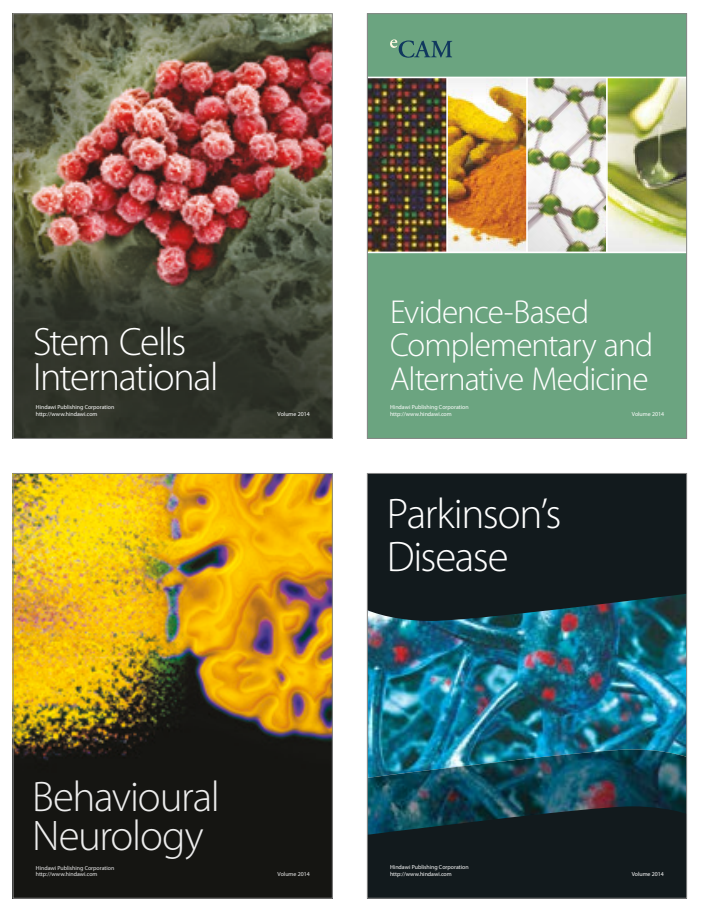
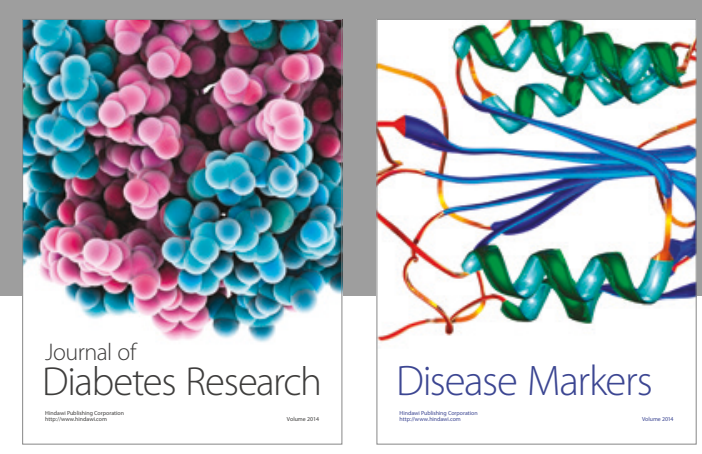

Disease Markers
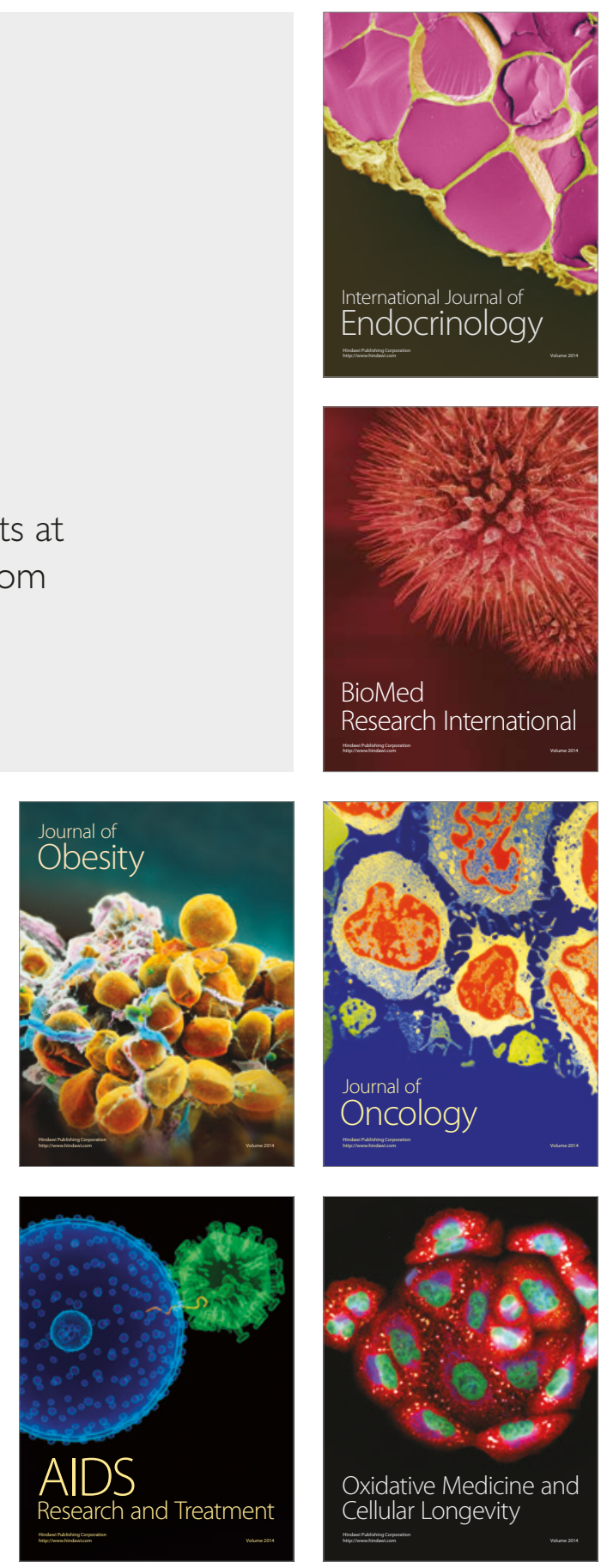